\title{
Skin injuries in hospitalized elderly
}

\section{Lesões de pele em idosos hospitalizados}

\section{Lesiones de piel en ancianos hospitalizados}

Clóris Regina Blanski Grden', Taís Ivastcheschen', Luciane Patrícia Andreani Cabral', Péricles Martim Reche ${ }^{1}$, Daniele Alaide de Siqueira de Oliveira², Danielle Bordin",

ORCID IDS

Grden CRB (iD https://orcid.org/0000-0001-6169-8826

Ivastcheschen T (iD https://orcid.org/0000-0001-8496-5990

Cabral LPA (iD https://orcid.org/0000-0001-9424-7431

Reche PM (iD https://orcid.org/0000-0001-7238-6318

Oliveira DAS (D) https://orcid.org/000-0002-4398-7963

Bordin D (ID https://orcid.org/0000-0001-7861-0384

\section{HOW TO CITE}

Grden CRB, Ivastcheschen T, Cabral LPA, Reche PM, Oliveira DAS, Bordin D. Skin injuries in hospitalized elderly. ESTIMA, Braz. J. Enterostomal Ther., 16:e4118. https://doi.org/10.30886/ estima.v16.639 IN

\begin{abstract}
Objective: To identify the prevalence of skin injuries in hospitalized elderly. Method: Cross-sectional study with 202 elderly patients selected for convenience and hospitalized in a hospital in Parana (Brazil). Data were collected between September 2017 and January 2018. The Mini-mental State Examination and the physical examination of nursing in the elderly were used. Data were submitted to the exploratory analysis and described by absolute frequency, percentage, means and standard deviations. Results: Women predominance (51\%), age range between 60-69 years (42.5\%), married (52\%) and low educational level (59.4\%). It was identified that 128 (63.4\%) elderly had clean scalp; 116(57.4\%), skin with normal coloring; 104 (51.5\%), normal turgor; 138 (68.3\%), normal temperature; 160 (79.2\%) of fine thickness; 101 (50\%), soft texture; 144 (71.3\%) with scar; 182 (90.1\%), sensitivity; and 152 (75.3\%), pruritus. Prevalence of eutrophic body mass index (38.6\%) and 176 (87.1\%) elderly had skin injuries; 152 (75.3\%) had primary injuries and 151 (74.7\%), secondary injuries. Conclusion: The study identified the high index of skin injuries in hospitalized elderly. The results are expected to make nurses aware of the importance of the physical examination of the skin as a fundamental step in planning preventive, monitoring and care actions.
\end{abstract}

DESCRIPTORS: Geriatric nursing; Physical exam; Elderly; Hospitalization.

\footnotetext{
${ }^{1}$ Universidade Estadual de Ponta Grossa - Departamento de Enfermagem e Saúde Pública - Ponta Grossa/PR - Brazil.

${ }^{2}$ Mölnlycke Health Care Brasil - Almirante Tamandaré/PR - Brazil.

Correspondence author: Clóris Regina Blanski Grden | Rua Teodoro Sampaio, 888 | ZIP Code: 84.036-070 - Ponta Grossa/PR, Brazil |

E-mail: reginablanski@hotmail.com

Received: Sept 012018 | Accepted: Dec 122018
} 


\section{RESUMO}

Objetivo: Identificar a prevalência de lesões de pele em idosos hospitalizados. Método: Pesquisa transversal com 202 idosos selecionados por conveniência e internados em um hospital do Paraná (Brasil). Os dados foram coletados entre setembro de 2017 e janeiro de 2018. Foram utilizados o Mini Exame do Estado Mental e o exame físico de enfermagem no idoso. Os dados foram submetidos à análise exploratória e descritos por frequência absoluta, percentual, médias e desvios-padrão. Resultados: predomínio de sexo feminino (51\%), faixa etária entre 60-69 anos (42,5\%), casados (52\%) e com baixa escolaridade (59,4\%). Identificou-se que 128 $(63,4 \%)$ idosos apresentavam couro cabeludo limpo; 116 (57,4\%), pele com coloração normal; 104 (51,5\%), turgor normal; 138 (68,3\%), temperatura normal; 160 (79,2\%), de espessura fina; 101 (50\%), textura macia; 144 (71,3\%), com cicatriz; 182 (90,1\%), sensibilidade; e 152 (75,3\%), prurido. Predominou índice de massa corporal eutrófico (38,6\%) e 176 (87,1\%) idosos apresentavam lesões de pele; 152 (75,3\%) possuíam lesões primárias e 151 (74,7\%), secundárias. Conclusão: o estudo identificou o alto de índice de lesões de pele em idosos internados. Espera-se que os resultados sensibilizem os enfermeiros quanto à importância do exame físico de pele como etapa fundamental para planejar ações de prevenção, monitoramento e cuidados.

DESCRITORES: Enfermagem geriátrica; Exame físico; Idoso; Hospitalização.

\section{RESUMEN}

Objetivo: Identificar la prevalencia de lesiones de piel en ancianos hospitalizados. Método: Investigación transversal con 202 ancianos seleccionados por conveniencia e internados en un hospital de Paraná (Brasil). Los datos fueron recolectados entre septiembre del 2017 y enero del 2018. Fueron utilizados el Mini Examen del Estado Mental y el examen físico de enfermería en el anciano. Los datos fueron sometidos al análisis exploratorio y fueron descritos por frecuencia absoluta, porcentual, medias y desvíos-estándar. Resultados: predominio del sexo femenino (51\%), edad entre 60-69 años (42,5\%), casados (52\%) y con baja escolaridad (59,4\%). Se identificó que 128 (63,4\%) ancianos presentaron el cuero cabelludo limpio; 116 (57,4\%) piel con coloración normal; 104 (51,5\%), turgencia normal; 138 (68,3\%), temperatura normal; 160 (79,2\%) de espesura fina; 101 (50\%), textura suave; 144 (71,3\%), con cicatriz; 182 (90,1\%), sensibilidad; y 152 (75,3\%), prurito. Predominó un índice de masa corporal eutrófico (38,6\%) y 176 (87,1\%) ancianos presentaban lesiones de piel; 152 (75,3\%) poseían lesiones primarias y 151 (74,7\%), secundarias. Conclusión: el estudio identificó un alto de índice de lesiones de piel en ancianos internados. Se espera que los resultados sensibilicen a los enfermeros con respecto a la importancia del examen físico de la piel como una etapa fundamental para planificar las acciones de prevención, monitoreo y cuidados.

DESCRIPTORES: Enfermería geriátrica; Examen físico; Anciano; Hospitalización.

\section{INTRODUCTION}

The changes that constitute and influence the aging process are complex and although this phenomenon is a growing world reality, the health services present numerous challenges to meet the health care needs of this population segment.

Psychological, functional and social changes interfere in the aging process, favoring the gradual loss of physiological reserves, the greater risk of contracting diseases and the general decline in the individual's intrinsic capacity ${ }^{1}$. Among the innumerable physiological changes that occur, it can highlight changes in the integumentary system, such as: reduction of dermal thickness, loss of elastic fibers, reduction of subcutaneous adipose tissue and reduction of capillaries in the skin ${ }^{2}$, among others, which may contribute to that the elderly become more susceptible to skin injuries.
Inadequate nutrition, invasive devices, mechanical strength, excess moisture, diaper use, and physical immobility are risk factors that predispose the appearance of the injuries ${ }^{3,4}$, which are characterized as one of the main complications that can affect hospitalized patients ${ }^{5,6}$, especially the elderly.

In general, this age segment tends to present several pathologies, a condition that contributes to hospitalization, with longer hospital stay and consequent increase in health costs ${ }^{7}$. In this context, the importance of the nurse performing the physical examination of the skin in the elderly with the direction of the early detection of injuries, traumas and other pathologies is emphasized, which can accentuate functional limitations, with repercussion for autonomy, independence and quality of life. 
It is understood that in the hospitalized elderly, the development of integumentary injuries is a negative indicator of the quality of $\mathrm{care}^{8}$, which is responsible for maintaining skin integrity.

\section{OBJECTIVE}

In view of the above, the objective of this study was to identify the prevalence of skin injuries in the elderly hospitalized in a teaching hospital through physical examination by the nurse.

\section{METHODS}

This is a cross-sectional study, realized with a convenience sample of 202 elderly people hospitalized in a medical clinic, in a medium-sized hospital in a municipality in the state of Parana (Brazil), from September 2017 to January 2018.

The criteria used for the selection of the sample were:

a. Age above or equal to 60 years;

b. Be hospitalized for at least 24 hours in the institution during the period of data collection;

c. Have cognitive ability to participate in the study ${ }^{9}$.

In the case of the elderly without cognitive conditions to answer the research questions, at the interview stage the caregiver/family member was invited to participate; for this the following inclusion criterion were listed:

a. Being 18 years or more;

b. Being a caregiver/family member;

c. Have lived with the elderly for at least three months.

Initially, the data collection performed at the hospitalization unit contemplated the cognitive screening through the Mini-mental State Examination (MMSE). The instrument has 11 items grouped into seven categories, represented by groups of specific cognitive functions: temporal orientation, spatial orientation, immediate memory, attention and calculation, evocation memory, language and visual constructive capacity ${ }^{10}$. The score ranges from zero to 30 , with the following cutoffs for evaluation: 13 points for illiterates; 18 points, low and average schooling; and 26 points, high schooling ${ }^{9}$.
In order to classify and characterize the sample, a sociodemographic and clinical questionnaire constructed specifically for the study was prepared. The elderly was submitted to the physical examination of nursing, which included: assessment of skin and attachments of the various segments, scalp and hair, face skin, turgor, skin temperature, thickness, texture, scar presence, skin sensitivity, pruritus, nails, nutrition measures (body mass index $[\mathrm{BMI}]$ ) and primary and secondary elementary injuries. The instrument was constructed based on references that address the semiology of the skin, with adaptation to the elderly patient ${ }^{11-13}$.

The data collection was realized by nurses residing in the elderly health and nursing students, scholars of scientific initiation, who were trained by a nurse specialist in stomatherapy, with clinical experience in the area, through a 45 hours theoretical-practical update on evaluation of skin in the elderly, which included the following themes: elemental injuries, pressure injuries, friction injuries, adhesive injuries, incontinence associated dermatitis, prevention and treatment for pressure injuries.

The data were tabulated and analyzed using Stata software ${ }^{\circledR}$, version 12 . These were submitted to the exploratory analysis and described by means of absolute frequency and percentage, means and their standard deviations.

The project was approved by the Ethics Committee of the State University of Ponta Grossa with an opinion $n^{\circ}$. 1.461.471 and by CAAE $n^{\circ}$ 66782217.9.0000.5689. The ethical precepts of voluntary and consensual participation of each subject were respected, according to the current resolution at the time of the research.

\section{RESULTS}

There was a predominance of women $(\mathrm{n}=103 ; 51 \%)$ and age group between 60-69 years $(\mathrm{n}=86 ; 42.5 \%)$, with a mean age of 71 years $( \pm 0.61)$ maximum of 98 years) (Table 1). Of the participants, 89 (44.2\%) were admitted to the surgical clinic, $44(21.8 \%)$ had a diagnosis of circulatory diseases (International Classification of Diseases [ICD 10]) and 166 (82.2\%) were hospitalized between 1-10 days, with an average time of 7.1 days $( \pm 0.59)$. In the evaluation of cognitive screening by MMSE, it was found that 75 (37.1\%) participants scored 
Table 1. Distribution of the sociodemographic and clinical characteristics of the elderly hospitalized in a teaching hospital. Paraná, Brazil, 2018.

\begin{tabular}{|c|c|c|}
\hline & Variables & n (\%) \\
\hline \multirow{2}{*}{ Gender } & Female & $103(51)$ \\
\hline & Male & 99 (49) \\
\hline \multirow{3}{*}{ Age group } & $60-69$ years & $86(42.5)$ \\
\hline & 70-79 years & $76(37.7)$ \\
\hline & $>80$ years & $40(19.8)$ \\
\hline \multirow{3}{*}{ Marital status } & Married & $105(52)$ \\
\hline & Single & $24(11.9)$ \\
\hline & Widower & $73(36.1)$ \\
\hline \multirow{4}{*}{ Schooling* } & High & $20(10)$ \\
\hline & Average & $30(14.8)$ \\
\hline & Low & $120(59.4)$ \\
\hline & Illiterate & $32(15.8)$ \\
\hline \multirow{3}{*}{ Skin color } & White & $147(72.8)$ \\
\hline & Brown & $36(17.8)$ \\
\hline & Black & $19(9.4)$ \\
\hline \multirow{4}{*}{ Admission center } & Surgical clinical & $89(44.1)$ \\
\hline & Medical clinic & $76(37.6)$ \\
\hline & Neurology clinic & $33(16.3)$ \\
\hline & Infectology clinic & $4(2)$ \\
\hline \multirow{5}{*}{ Diagnosis according to ICD $10^{* *}$} & Diseases of the circulatory system & $44(21.8)$ \\
\hline & Diseases of the respiratory tract & $32(15.9)$ \\
\hline & Diseases of the digestive system & $26(12.9)$ \\
\hline & Musculoskeletal and connective tissue diseases & $28(13.9)$ \\
\hline & Others & $72(35.5)$ \\
\hline \multirow{3}{*}{ Hospital stay } & $1-10$ days & $166(82.2)$ \\
\hline & 11-20 days & $23(11.4)$ \\
\hline & 21 days or more & $13(6.4)$ \\
\hline \multirow{2}{*}{ Chronic disease } & Yes & $170(84.2)$ \\
\hline & No & $32(15.8)$ \\
\hline \multirow{2}{*}{ Smoking } & Yes & $58(28.7)$ \\
\hline & No & $144(71.3)$ \\
\hline \multirow{2}{*}{ Alcoholism } & Yes & $32(15.8)$ \\
\hline & No & $170(84.2)$ \\
\hline \multirow{2}{*}{ Diet } & Oral & $174(86.1)$ \\
\hline & Enteral & $28(13.9)$ \\
\hline \multirow{2}{*}{ Use of medication } & Yes & $197(97.5)$ \\
\hline & No & $5(2.5)$ \\
\hline \multirow{2}{*}{ Use of medical devices } & Yes & $150(74.3)$ \\
\hline & No & $52(25.7)$ \\
\hline \multirow{4}{*}{ Mobility } & Independent & $76(37.6)$ \\
\hline & Professional assistance & $35(17.3)$ \\
\hline & Use of technologies*** & $20(10)$ \\
\hline & Bed restricted & $71(35)$ \\
\hline \multirow{4}{*}{ MMSE } & $0-13$ points & $58(28.7)$ \\
\hline & $14-18$ points & $24(12)$ \\
\hline & $19-25$ points & 75 (37.1) \\
\hline & 26-30 points & $45(22.2)$ \\
\hline \multirow{5}{*}{ Braden Scale } & $<9$ points & $07(3.5)$ \\
\hline & 10-12 points & $19(9.4)$ \\
\hline & 13-14 points & $30(14.8)$ \\
\hline & 15-18 points & $56(27.7)$ \\
\hline & 19-23 points & $90(44.5)$ \\
\hline
\end{tabular}

* Schooling: high ( $\geq 8$ years of study); average (4-8 years incomplete); Iow (1-4 years incomplete).** Other Diagnosis: includes chapters I, II, III, IV, V, VI, VII, XI, XIV, XX and XXI of ICD 10. *** Use of technologies: includes walker, cane and crutch. ICD $10=$ International Classification of Diseases; MMSE= Mini Mental State Examination. Source: Authors (2018). 
between 19-25 points. The other clinical conditions are presented in Table 1.

As to the physical examination of the integumentary system, 128 (63.4\%) interviewed had scalp/clean hair; 116 (57.4\%), skin with normal coloring; 160 (79.2\%), fine thickness; 101 (50\%), soft texture; 144 (71.3\%), scar;
$182(90.1 \%)$, sensitivity; and $152(75.3 \%)$, pruritus. The majority $(\mathrm{n}=78,38.6 \%)$ were evaluated with eutrophic BMI (22-27). It was found that 176 (87.1\%) participants had some elemental lesion (Table 2).

It were identified 364 primary elemental injuries, of which 236 (64.8\%) were color changes; 74 (20.4\%),

Table 2. Distribution of the characteristics of the integumentary physical examination of the elderly hospitalized in a teaching hospital. Paraná, Brazil, 2018.

\begin{tabular}{|c|c|c|}
\hline \multicolumn{2}{|c|}{ Variables } & \multirow{2}{*}{\begin{tabular}{|c|}
$\mathbf{n}(\%)$ \\
$11(5.4)$
\end{tabular}} \\
\hline \multirow{7}{*}{ Scalp/Hair } & Dandruff & \\
\hline & Seborrhea & $4(2)$ \\
\hline & Alopecia & $4(2)$ \\
\hline & Greasy & $13(6.4)$ \\
\hline & Dry & $29(14.4)$ \\
\hline & Unclean & $13(6.4)$ \\
\hline & Clean & $128(63.4)$ \\
\hline \multirow{5}{*}{ Coloring } & Cyanosis & $3(1.5)$ \\
\hline & Flush & $27(13.4)$ \\
\hline & Jaundiced & $8(4)$ \\
\hline & Pale & $48(23.8)$ \\
\hline & Normal & $116(57.4)$ \\
\hline \multirow{2}{*}{ Turgor } & Decreased & $98(48.5)$ \\
\hline & Normal & $104(51.5)$ \\
\hline \multirow{2}{*}{ Temperature } & Cold & $64(31.7)$ \\
\hline & Warm & $138(68.3)$ \\
\hline \multirow{2}{*}{ Thickness } & Slim & $160(79.2)$ \\
\hline & Thick & $42(20.8)$ \\
\hline \multirow{2}{*}{ Texture } & Soft & $101(50)$ \\
\hline & Dry & $101(50)$ \\
\hline \multirow{2}{*}{ Presence of scar } & Yes & $144(71.3)$ \\
\hline & No & $58(28.7)$ \\
\hline \multirow{2}{*}{ Sensitivity } & Yes & $182(90.1)$ \\
\hline & No & $20(9.9)$ \\
\hline \multirow{2}{*}{ Itching } & Yes & $152(75.3)$ \\
\hline & No & $50(24.7)$ \\
\hline \multirow{7}{*}{ Nails } & Transparent & $28(14)$ \\
\hline & Smooth & $19(9.4)$ \\
\hline & Transparent and smooth & $54(26.7)$ \\
\hline & Convex & $15(7.4)$ \\
\hline & Concave & $15(7.4)$ \\
\hline & Patchs & $32(15.8)$ \\
\hline & Clubbing & $39(19.3)$ \\
\hline \multirow{3}{*}{ BMI } & $<22$ & $56(27.7)$ \\
\hline & $22-27$ & $78(38.6)$ \\
\hline & $>27$ & $68(33.7)$ \\
\hline \multirow{2}{*}{ Presents injury } & Yes & $176(87.1)$ \\
\hline & No & $26(12.9)$ \\
\hline Presents elemental injuries & Yes & $152(75.3)$ \\
\hline Primary & No & $50(24.7)$ \\
\hline Presents elemental injuries & Yes & $151(74.7)$ \\
\hline Secondary & No & $51(25.3)$ \\
\hline
\end{tabular}

*Body mass index (BMI): <22 low weight; 22-27 eutrophic; > 27 overweight. Source: Authors (2018). 
liquid collections; and 54 (14.8\%), solid collections. The secondary elementary injuries totaled 324 , of which $158(48.8 \%)$ were changes in texture and thickness and 166 (51.2\%), tissue losses. Elementary injuries are alterations in the cutaneous tegument determined by inflammatory, degenerative, circulatory or neoplastic processes, by disorders of metabolism or by defects of formation ${ }^{11}$. The primary elemental injuries are color changes, liquid collections and solid collections, whereas secondary elementary injuries are changes in texture, thickness and tissue losses ${ }^{11}$.

\section{DISCUSSION}

Among the participants, there was a predominance of women, in line with the results of national surveys on injuries among hospitalized elderly ${ }^{5,14}$ and in the community ${ }^{4}$. Hormonal alterations from the aging process may contribute to the appearance of skin injuries in the elderly 8 .

For the age variable, both the mean age and the age group identified are like the descriptive and exploratory research performed with 55 hospitalized elderly in Paraiba, in which a higher prevalence of injuries was observed in the elderly ${ }^{8}$; this may be justified by the late search for health services or the lack of follow-up service to the elderly.

The analysis of marital status pointed out a higher proportion of married elderly, as expected for the age group of the study population and identified in an exploratory research on the evaluation of skin in hospitalized elderly, in which $50 \%$ of the participants were married ${ }^{14}$. It is understood the married condition as a positive aspect for the elderly regarding the assistance in life activities and instrumental of daily life, collaborating for actions of prevention and care of the skin.

The expressive percentage of elderly with low educational level identified in this study is similar to the results of the cross-sectional, retrospective study and through data recorded in 1.168 medical records of the Medical Archive Service of the Hospital of Clinics of the Federal University of Triangulo Mineiro ${ }^{5}$, in which participants predominated with low level of education. One possible explanation can be attributed to the profile of the community served by the hospital, linked to the
Unified Health System, in which elderly people with unfavorable economic conditions predominate, most of whom did not have access to the education system.

As for white skin color, it becomes more susceptible to integumentary injuries due to its histological characteristics, such as less melanin protection and fewer collagen fibers ${ }^{15,16}$. In agreement with the findings, the transversal research realized in Palmas with 259 elderly people stands out, of which $66.7 \%$ had white skin color ${ }^{16}$.

For the variables period and average time of hospitalization, the findings differ from other national studies, which identified a longer average time of hospitalization (12.7 and 10 days) ${ }^{13,14}$, which can be attributed to the fact that the interviewees were hospitalized in sectors considered of high hospital turnover.

Most of the elderly reported chronic diseases, a condition expected by the characteristic of the sample being with hospitalized elderly. Authors point out that the presence of injuries is more prevalent among the elderly with at least one chronic disease, especially diabetes, cardiovascular diseases and immunosupressors, which may alter the healing process ${ }^{4}$. The findings are similar to the descriptive and exploratory research that is part of the Health, Well-being and Aging Study (HWBA), developed to outline the living and health conditions of elderly people living in the city of Sao Paulo, where 54.7\% of the 2143 elderly people they had chronic diseases ${ }^{4}$.

Although the majority of the interviewees reported not being a smoker or an alcoholic, these habits are considered public health problems, due to the high mortality of the diseases from these conditions ${ }^{17}$. On the skin, such substances can cause tissue breakage, injuring cells, resulting in premature aging and interfering with skin integrity ${ }^{17}$.

Among the participants, it was verified the predominance of oral diet. Nutrition is one of the intrinsic factors that affects the skin and its functionality ${ }^{18}$. Authors indicate the association between nutrition and the delay of healing with the development of injuries ${ }^{19}$.

The high use of medication identified in the elderly in this study ${ }^{18}$ is in line with the prospective cohort study conducted in a teaching hospital with 215 elderly people, which revealed that $69.7 \%$ used medication ${ }^{20}$. Drugs can cause changes that may decrease skin sensitivity and cause allergies. 
The use of medical and mobility devices can contribute to the occurrence of traumas and restrictions. During hospitalization, the elderly may be subject to the use of devices necessary for their treatment, such as catheters, tubes, drains, probes and others. However, medical devices that have a skin adherence action favor rupture of cutaneous integrity from their manipulation and removal, while those of mobility have an impact on daily care and position exchange ${ }^{3}$.

The high scores obtained in cognitive screening (MMSE) by the elderly participants can be attributed to the age characteristic of the sample, composed predominantly of young and active elderly. However, no research has been found on cognitive screening in the elderly with skin injuries for comparison with the findings.

In the accomplishment of the integumentary physical examination, it was observed the scarcity of studies about the subject, specifically in the elderly age segment. However, the relevance of the identification and early screening of skin injuries through the integumentary physical examination by the nursing team is understood.

In the hospital context, the elderly presented a high number of cutaneous injuries, especially those called elementary, defined as any structural modification of the skin and that have different causes, such as circulatory, hyperplastic, metabolic, inflammatory and degenerative ${ }^{21}$.

Among the elemental injuries, the predominance of color changes, which affect the epidermis and the dermis, have no relief or consistency and occur by vasodilatation, constriction or extravasation of red blood cells and by decrease or increase of melanin or deposits of others pigments and substances ${ }^{11}$. Likewise, there has been a high amount of texture changes and tissue thickness and loss which may arise from pathological elimination or destruction and repair in subcutaneous tissues ${ }^{11}$.

Cross-sectional design was a limiting factor in the evaluation between cause and effect relationships. In addition, sampling is representative of a local community, so it does not allow generalization of results to other territories. It is suggested that investigations realized with this age group may include the home visit to collect information, as well as possible evaluations of the professionals' knowledge about the subject and their actions.

It is pointed out that the scarcity of epidemiological studies on skin injuries in the elderly age segment made it difficult to compare the findings of the present investigation, which justifies the necessity for epidemiological studies especially with this population.

\section{CONCLUSION}

The study identified the high prevalence of skin injuries in the elderly hospitalized in a teaching hospital through physical examination by the nurse. The integumentary injuries may interfere with the functional status and contribute to an increase in length of hospital stay and premature mortality.

In this context, it is considered important that the professional nurse perform the physical examination of the skin with a careful evaluation to identify the changes, whether natural or pathological, that the elderly can present, thus enabling the construction of gerontological care plans the specific needs of this age group.

\section{AUTHORS' CONTRIBUTION}

Conceptualization, Grden CRB; Ivastcheschen T; Cabral LAP; Reche PM; Methodology, Grden CRB; Ivastcheschen T; Reche PM; Oliveira de DAS; Investigation, Ivastcheschen T; Oliveira de DAS; Cabral LAP; Writing, Grden CRB; Ivastcheschen T; Bordin D; Writing - Review \& Editing, Grden CRB; Ivastcheschen T; Cabral LAP; Bordin D; Reche PM; Supervision, Grden CRB.

\section{REFERENCES}

1. Universidade Federal do Maranhão - UNA-SUS/UFMA; Motta LB, organizadora. Conceitos básicos sobre envelhecimento. UNASUS/UFMA. São Luís, 2013.

2. Montanari T. Histologia: texto, atlas e roteiro de aulas práticas. 3a ed. Ponto Alegre: Edição do Autor; 2016.
3. Busanello J, Pinto DM, Schons ES, Baumgart D, Poll MA. Cuidados de enfermagem ao paciente adulto: prevenção de lesões cutaneomucosas e segurança do paciente. Rev Enferm da UFSM. 2015;5(4):597-606. https://doi. org/10.5902/2179769216310 
4. Duim E, De Sá FHC, Duarte YAO, De Oliveira RCB, Lebrão ML. Prevalence and characteristics of lesions in elderly people living in the community. Rev Esc Enferm USP. 2015;49(Speciallssue):50-6. https://doi.org/10.1590/ S0080-623420150000700008

5. Chavaglia SRR, OhI RIB, Ferreira LA, Santiago VR, Abdanur AF, Soares AS. Caracterização de pacientes com lesão cutânea em unidades de internação médica e cirúrgica. Rev Enferm UFPE on line. 2015;9(1):183-92.

6. Mittag BF, Krause TCC, Roehrs H, Meier MJ, Danski MTR. Cuidados com lesão de pele: ações da enfermagem. ESTIMA, Braz J Enterestomal Ther. 2017;15(1):19-25. https://doi.org/10.5327/Z1806-3144201700010004

7. Queiroz DB, Oliveira LC, Araújo CM, Reis LA. Perfil de internações de idosos em uma clínica de neurociências de um hospital público. Rev Enferm Contemp. 2016;5(1):1624. https://doi.org/10.17267/2317-3378rec.v5i1.441

8. Bezerra AF, Silva JB, Silva JSN, Vigolvino LP, Meneses LBA. Lesões de pele em idosos hospitalizados: estudo de ocorrência. Anais do IV Congresso Internacional de Envelhecimento Humano; 2015 Set 21-26; Campina Grande. 2015;2(1).

9. Bertolucci PH, Brucki SM, Campacci SR, Juliano Y. The MiniMental State Examination in an outpatient population: influence of literacy. Arq Neuro-psiquiatr. 1994;52(1):17. https://doi.org/10.1590/S0004-282X1994000100001

10. Folstein MF, Folstein SE, McHugh PR. "Mini-mental state": a practical method for grading the cognitive state of patients for the clinician. J Psychiatr Res. 1975;12(3):18998. https://doi.org/10.1016/0022-3956(75)90026-6

11. Bolognia JL, Jorizzo JL, Rapini RP. Dermatologia. 2a ed. Rio de Janeiro: Elsevier; 2011.

12. Giaretta VMA, Silva AM, Renó ACM, Aguiar DAF, Arantes CMS, Posso MBS. Proposta de uma escala para avaliar o turgor da pele de idosos. Rev Cienc Saude. 2016;1(1):17.

13. Silva CFR, Santana RF, Oliveira BGRB, Carmo TG. High prevalence of skin and wound care of hospitalized elderly in Brazil: a prospective observational study. BMC Research Notes. 2017;10(81). https://doi.org/10.1186/ s13104-017-2410-6

14. Chibante CLP, Santo FHE, Santos TD. Perfil de clientes hospitalizados com lesões cutâneas. Rev Cuba Enferm. 2015;31(4).

15. Kohl E, Steinbauer J, Landthaler M, Szeimies RM. Skin ageing. J Eur Acad Dermatol Venereol. 2011;25(8):87384. https://doi.org/10.1111/j.1468-3083.2010.03963.x

16. Silva LMT. Idosos hospitalizados em risco de desenvolver lesão por pressão: contribuição do enfermeiro [trabalho de conclusão de curso]. Niterói: Universidade Federal Fluminense, Curso de Enfermagem; 2016.

17. Carvalho A, Borda CC, Moreira DM, Pereira MAR, Mário RF, Zychar BC. Envelhecimento cutâneo induzido pelo tabagismo. Atas de Ciências da Saúde. 2016;3(3).

18. Murphree RW. Impairments in skin integrity. Nurs Clin North Am. 2017;52(3):405-17. https://doi.org/10.1016/j. cnur.2017.04.008

19. Oliveira KDL, Haack A, Fortes RC. Terapia nutricional na lesão por pressão: revisão sistemática. Rev Bras Geriatr Gerontol. 2017;20(4). https://doi.org/10.1590/198122562017020.160195

20. Vieira CPB, Sá MS, Madeira MZA, Luz MHBA. Caracterização e fatores de risco para úlceras por pressão na pessoa idosa hospitalizada. Rev Rene. 2014;15(4):650-8. https:// doi.org/10.15253/2175-6783.2014000400012

21. Porto CC. Semiologia médica.7a ed. Rio de Janeiro: Guanabara-Koogan; 2014. 